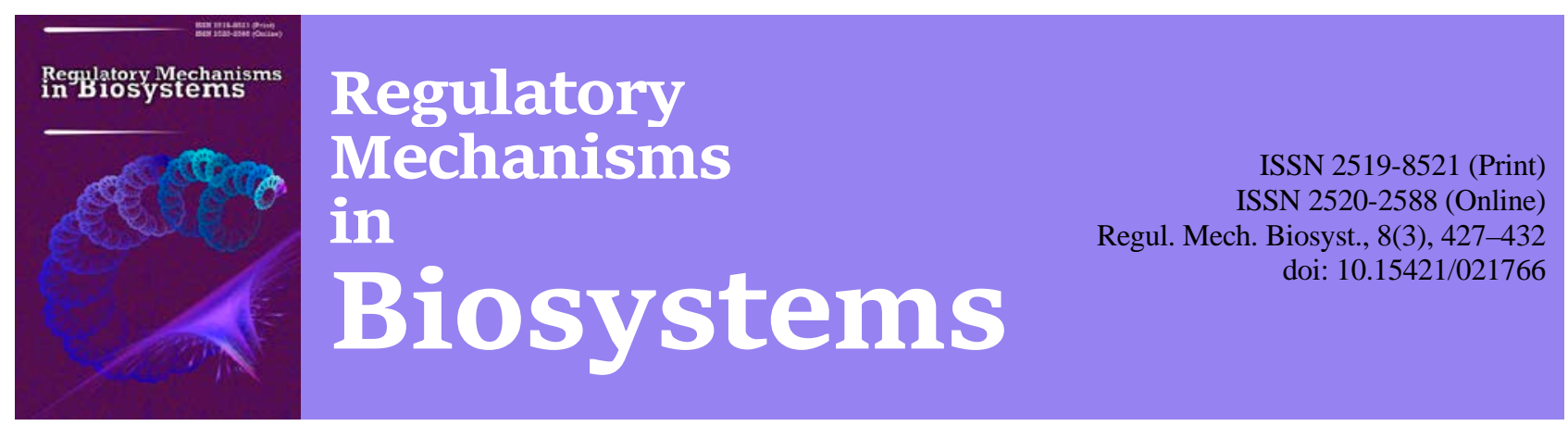

\title{
The influence of Metisevit \\ on biochemical and morphological indicators of blood of piglets under nitrate loading
}

\author{
B. Gutyj, K. Leskiv, A. Shcherbatyy, V. Pritsak, V. Fedorovych, O. Fedorovych, V. Rusyn, I. Kolomiiets \\ Stepan Gzhytskyi National University of Veterinary Medicine and Biotechnologies, Lviv, Ukraine
}

Article info

Received 04.07.2017

Received in revised form 23.07.2017

Accepted 29.07.2017

Stepan Gzhytskyi National University of Veterinary

Medicine and Biotechnologies,

Pekarska Str., 50

Lviv, 79010, Ukraine.

Tel.: +38-068-136-20-54

E-mail: bvh@ukr.net
Gutyj, B., Leskiv, K., Shcherbatyy, A., Pritsak, V., Fedorovych, V., Fedorovych, O., Rusyn, V., \& Kolomiiets, I. (2017). The influence of Metisevit on biochemical and morphological indicators of blood of piglets under nitrate loading. Regulatory Mechanisms in Biosystems, 8(3), 427-432. doi: 10.15421/021766

The article presents the results of research on the influence of the developed complex preparation Metisevit on the dynamics of morphological and biochemical blood indicators of piglets under nitrate loading. The research established that sodium nitrate intoxication causes disbalance of the physiological level of hematological indicators of the tested animals' organisms. This was indicated by the manifestations of subclinical chronic nitrate-nitrite toxicosis: the increase in the level of nitrates, nitrites and methemoglobin in the blood. After prolonged feeding of the piglets with sodium nitrate at a dose of $0.3 \mathrm{~g}$ nitrate ion $/ \mathrm{kg}$, the concentration of nitrates and nitrites in the blood serum reached its maximum on the 60th day of the experiment. Also, the number of leukocytes and erythrocytes in the blood increased, and the activity of aspartate- and alanineaminotransferase in the blood serum increased. We rank the extent of liver intoxication with nitrates according to intensity of aminotransferase in the blood serum of the tested piglets. The normalization of morphological and biochemical blood indicators of piglets under nitrate-nitrite intoxication requires usage of a preparation which contains vitamins, zeolites and antioxidants. If the fodder contains high doses of nitrates, $1.0 \mathrm{mg} / \mathrm{kg}$ dose of Metisevit is added to the fodder for preventing subclinical nitrate-nitrite toxicosis. Metisevit contains the following agents: phenozan acid, methionine, zeolite, selenium, vitamins $\mathrm{E}$ and $\mathrm{C}$. The research conducted proved the feasibility of using Metisevit for preventing chronic nitrate-nitrite toxicosis in piglets. This preparation caused a decrease in the concentration of nitrates, nitrites and in the level of methemoglobin in the blood of piglets. Usage of Metisevit on piglets showed normalization of the number of erythrocytes and hemoglobin in the blood on the 10th day, and normalization of ASAT and ALAT on 30th and 90th days. The mechanism of Metisevit activity is connected with the direct contribution of its elements to the inhibition of the processes of absorbing metabolites which cause a toxic effect on the cell membranes of an animal's organism. The absorbing activity of zeolite leads to decrease in concentration of agents which can be substrates for processes of peroxidation of lipids in the alimentary canal, and also to elimination of toxic prooxidant metabolites from the blood. This process occurs through osmosis and diffusion of these elements in the capillaries of microvilli of the small intestine and through their further fixation on sorbent granules.

Keywords: toxicology; sodium nitrate; vitamins; zeolite; phenozan acid; methionine

\section{Introduction}

Swine breeding is an important sphere of livestock farming in Ukraine; it produces the bulk of food products of animal origin. The main role in development and progressive functioning of this sphere is swine reproduction. The method of intensive pig rearing in the conditions of farms of different types using high-yielding breeds and industrial technology of maintenance is significantly different from the traditional methods of rearing. It should be noted that in such conditions, early weaning of piglets, transferring animals etc. are stress factors which contribute to the decrease in neonatal adaptation of the organism of piglets, which causes disbalance between the activity of the antioxidant system and lipid peroxidation, reducing the animals to a stressed condition. This is followed by stunting, increase of incidence of disease and mortality of pigs, reproductive dysfunctions and decrease in the quality of the meat products (Todoriuk et al., 2016; Todoriuk et al., 2017). Also, it should be noted that environmental pollution with nitrates and their undesirable impact on pigs' organisms makes the study of the mechanism of nitrates and their toxic effect especially relevant both on a theoretical and practical level. Questions connected with nitrate-nitrite toxicosis in animals and birds have been addressed in numerous scientific works by Ukrainian and foreign researchers (Douglas, 1970; Hegesh and Shiloah, 1982; Horner, 1982; Nordkvist et al., 1984; Saito et al., 1996; Medeiros et al., 2003; Aslani and Vojdani, 2007; Issi et al., 2008; Harvey et al., 2010; Gutyj et al., 2016; Katabami et al., 2016). Much of this research has explored the peculiarities of metabolism and physiological dysfunctions.

Medicines have been observed to be highly effective in cases of nitrate-nitrite intoxication and this can be only achieved using complex therapy. In particular, this is directed towards the alleviating the consequences of incorrect application of rearing and feeding technology and also towards increase in resistance of the organism. During the last few years, the practice of veterinary medicine has accumulated a significant amount of experience in using different vitamin preparations for treating animals suffering from nitrate intoxication. The aim of this research is to study the impact of Metisevit on biochemical and morphological indicators of the blood of piglets under nitrate loading. 


\section{Materials and methods}

The studied objects were 10 three month old piglets of the Yorkshire breed. The research was conducted in "Komarnovs'ke" Scientific-teaching Animal Rearing Centre of Lviv National University of Veterinary Medicine and Biotechnologies named after S. Z. Gzhytskyi. According to the method of analogue-groups, two groups were formed: control and experimental. The piglets of the control group were fed with $\mathrm{NaNO}_{3}$ at doses of $0.3 \mathrm{~g}$ of nitrate ion $/ \mathrm{kg}$ of body weight once a day. The piglets of the experimental group were fed with $\mathrm{NaNO}_{3}$ at doses of $0.3 \mathrm{~g}$ of ntrate ion $/ \mathrm{kg}$ of body weight and Metisevit at doses of $1.0 \mathrm{mg} / \mathrm{kg}$ of body weight once a day. Metisevit consists of the following substances: phenozan acid, methionine, zeolite, selenium, vitamins E and C.

Maintenance, feeding, care and all manipulations of the animals were conducted according to European convention for the protection of vertebrate animals used for experimental and other scientific purposes (Strasbourg, 1986) and "General ethical principles of conducting experiments on animals" agreed at The First National Congress in Bioethics (Kyiv, 2001). The experiments were conducted in accordance with the principles of humanity set out in the directive of the European Community.

The number of erythrocytes and leukocytes was calculated using a hemocytometer in accordance with the recognized methods. The level of blood hemoglobin was calculated using the cyanhemoglobin method with photoelectric colorimeter-M according to V. Derviz's and A. Vorobiev's method. Concentration of methemoglobin was calculated according to the method of Boyarchuk and co-authors (Vlizlo, 2012). Using standard sets of reagents of the firm "Simko Ltd" (Czech Republic), we measured the activity of aspartate aminotransferase (AST; EC 2.6.1.1) and alanine aminotransferase (ALT; EC 2.6.1.2) in the blood serum according to the Reitman Frankel dinitrophenylhydrazine method.

The results were analyzed statistically using ANOVA. Differences between the samples were considered statistically significant at $\mathrm{P}<0.05$. In the figures $\mathrm{x} \pm \mathrm{SD}$ is presented.

\section{Results}

An important diagnostic indicator of the toxic effect of nitrates and nitrites on the organism of animals is measuring the concentration of nitrates, nitrites and methemoglobin in the blood (Robert et al., 1999; Gutyj et al., 2016). According to data from the literature, it is well known that nitrates are present at a low level in the blood of pigs and that nitrites are absent.

When feeding piglets with fodder containing nitrates at a dose of $0.3 \mathrm{~g}$ of nitrate ion $/ \mathrm{kg}$ of body weight, we observed an increase in the concentration of nitrates and nitrites among the piglets throughout the experiment (Fig. 1, 2). By the 10th day of the experiment, the concentration of nitrates in the blood of piglets from the control group had increased to $0.150 \pm 0.005 \mathrm{mg} / \mathrm{l}$, and the concentration of nitrites had increased to $0.00713 \pm 0.00032 \mathrm{mg} / \mathrm{l}$. By the 30th day of the experiment, the concentration of nitrates and nitrites had increased respectively by 3.01 and 7.71 times compared to blood indicators on the 10th day of the experiment. On the 60th day of the experiment, the concentration of nitrates and nitrites in the blood of piglets from the control group reached its maximum, and was respectively: nitrates $0.664 \pm 0.0073 \mathrm{mg} /$, nitrites $0.0281 \pm 0.00023 \mathrm{mg} / \mathrm{l}$. On the 90th day of the experiment, we observed a decrease in the concentration of nitrates and nitrites in the blood of animals from the control group, where the animals received nitrate loading. This, perhaps, could be explained by the adaptation of the organism to prolonged feeding with sodium nitrate.

Feeding piglets with fodder containing sodium nitrate and Metisevit contributed to decrease in the concentration of nitrates and nitrites in their blood. On the 10th day of the experiment, we observed a decrease in the concentration of nitrates in the blood of animals from the experimental group by $34.7 \%$ compared to the animals from the control group. On the 30th day of the experiment, the concentration of nitrates in the blood of piglets from the experimental group was growing, but was lower by $52.5 \%$ compared to the animals from the control group. Therefore, using Metisevit contributed to a decrease in concentration of nitrates in the blood of piglets from the experimental group. Apart from decrease in concentration of nitrates in the blood of animals from the experimental group, a decrease in concentration of nitrites was observed, as shown in Figure 2.

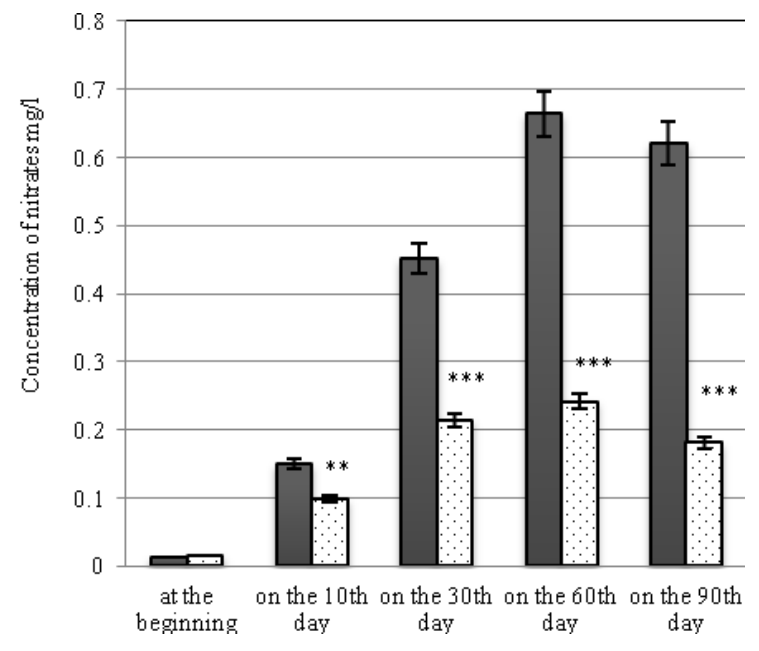

Fig. 1. The impact of Metisevit on the concentration of nitrates in the blood of piglets under nitrate loading: dark column - control group, bright column - experimental group $(\mathrm{n}=5, \mathrm{x} \pm \mathrm{SD}) ;^{*}-\mathrm{P}<0.05,{ }^{* *}-\mathrm{P}<0.01,{ }^{* * *}-\mathrm{P}<0.001$

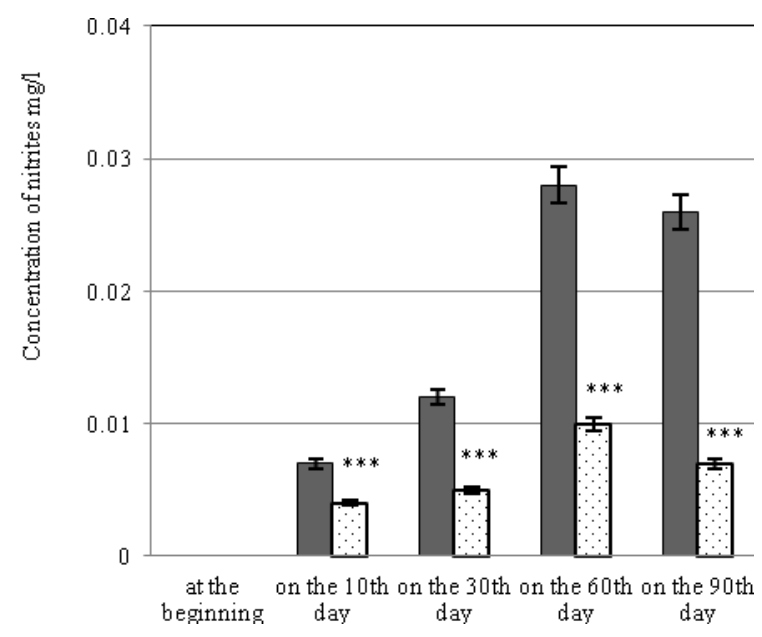

Fig. 2. The impact of Metisevit on the concentration of nitrites in the blood of piglets under nitrate loading: see Fig. 1

On the 10th day of the experiment, the concentration of nitrites in the blood of animals from the experimental group was $0.00442 \pm$ $0.00031 \mathrm{mg} / \mathrm{l}$, whereas the concentration of nitrites in the blood of piglets from the control group was $0.00713 \pm 0.00032 \mathrm{mg} / \mathrm{l}$. By the 30th day of the experiment, the concentration of nitrites in the blood of animals had decreased by $49.8 \%$ in relation to the indicators of piglets from the control group. By the 60th day of experiment, the concentration of nitrites had insignificantly increased compared to the previous days of the experiment; nevertheless it was lower than the indicators of the animals from the control group. On the 90th day of the experiment, the concentration of nitrites in the blood of animals from the experimental group which were given Metisevit equaled the values from the 10th day of the experiment. As is known, one of the main indicators of nitrate-nitrite toxicosis is formation of methemoglobin. Our experiments showed that feeding piglets with sodium nitrate at a dose $0.3 \mathrm{~g}$ of nitrate ion $/ \mathrm{kg}$ of body weight caused 
an increase in the level of methemoglobin among piglets from the control group throughout the experiment (Fig 3). A possible increase in the content of methemoglobin in the blood of piglets from the control group was observed on the 30th, 60th and 90th days of the experiment, where its level increased in $2.43,4.71$ and 4.25 relative to the initial values. The high level of methemoglobin in the blood of piglets during the abovementioned periods is connected with increase of concentration of nitrates and nitrites during the same periods of the experiments.

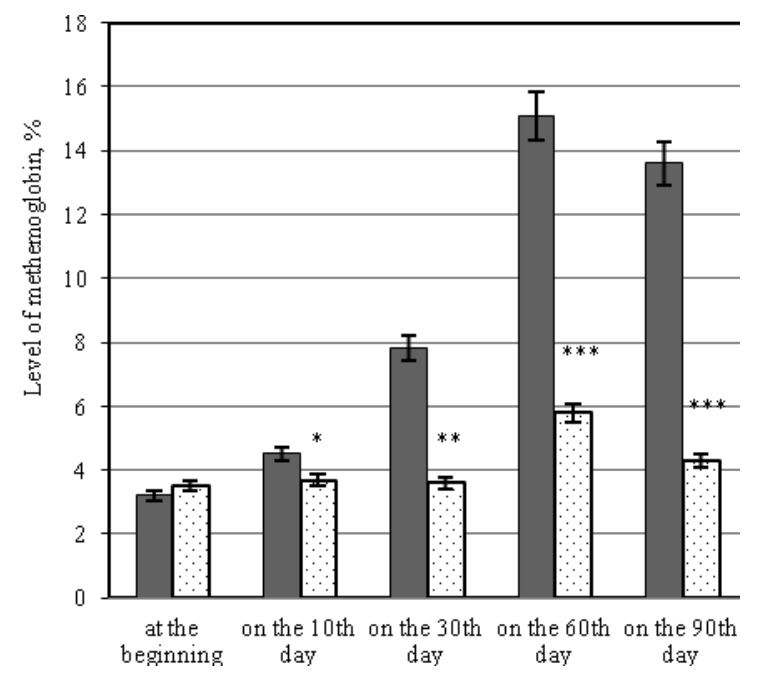

Fig. 3. The impact of Metisevit on the level of methemoglobin in the blood of piglets under nitrate loading: see Fig. 1

Using Metisevit with sodium nitrate prevented the development of nitrate-nitrite toxicosis among piglets of the experimental group. On the 10th day of the experiment, the level of methemoglobin in the blood of animals which were fed with fodder containing Metisevit was lower by $17.8 \%$ compared to animals of the control group. On the 30th day of experiment, the level of methemoglobin in blood of piglets from the experimental group was $3.6 \pm 0.039 \%$, whereas among the animals from the control group, this indicator equaled $7,8 \pm 0.051 \%$. On the 60th day of the experiment, we observed a high level of methemoglobin in the blood of animals from the experimental group, which is related to high content of nitrates and nitrites in the blood of piglets in this period of the experiment. In this period, the level of methemoglobin in the blood of animals from the experimental group was 2.60 times lower compared to indicators of methemoglobin in the blood of animals from the control group. On the 90th day of the experiment, the level of methemoglobin in the blood of piglets from the experimental group fluctuated within the values $4.3 \pm 0.032 \%$.

It is known that hemoglobin is an oxygen pigment of blood, which mainly acts as an agent which transports molecular oxygen from the breathing organs to the tissues. As is seen from the data in Figure 4, the level of hemoglobin in the blood of animals from the control group grew throughout the experiment. This is related to resistive and adaptive reactions of the organism to formation of methemoglobin. In particular, it fluctuated within the values of 98.4 $\pm 1.32 \mathrm{~g} /$ l. to $108.8 \pm 1.17 \mathrm{~g} / \mathrm{l}$. The highest level of hemoglobin in blood was observed on the 60th day of the experiment among animals from the control group, where it increased by $10.6 \%$ even before feeding with nitrates. Using Metisevit caused stabilization of the level of hemoglobin in the blood of the tested piglets, which is shown by the results of experiment presented in Figure 4.

Erythrocytes are the most numerous clusters of blood cells. As is shown in Figure 5, feeding piglets of the control group with sodium nitrate at a dose of $0.3 \mathrm{~g}$ of nitrate-ion $/ \mathrm{kg}$ of body weight caused increase in erythrocytes: on the 30th day of the experiment the level of erythrocytes was higher by $6.3 \%$ compared to initial values. The highest number of erythrocytes in the blood of piglets from the control group was observed on the 60th day of experiment $7.18 \pm 0.12 \mathrm{~T} /$. This is explained by resistive and adaptive reactions of the organism to a high level of methemoglobin, which is directed to the transportation of oxygen to the tissues as a result of development of hemic hypoxia. Feeding piglets with fodder which contains methyphenum contributed to normalization of the number of erythrocytes in the blood of animals from the experimental group.

The results of tests on piglets (Fig. 6) showed that feeding with sodium nitrate caused gradual increase in the number of leukocytes in the blood throughout the experiment: on the 10th day the level of leukocytes had increased by $7.9 \%$, on the 30th day - by $10.9 \%$, on the 60 th day - by $14.9 \%$, on the 90 th day - by $9.9 \%$.

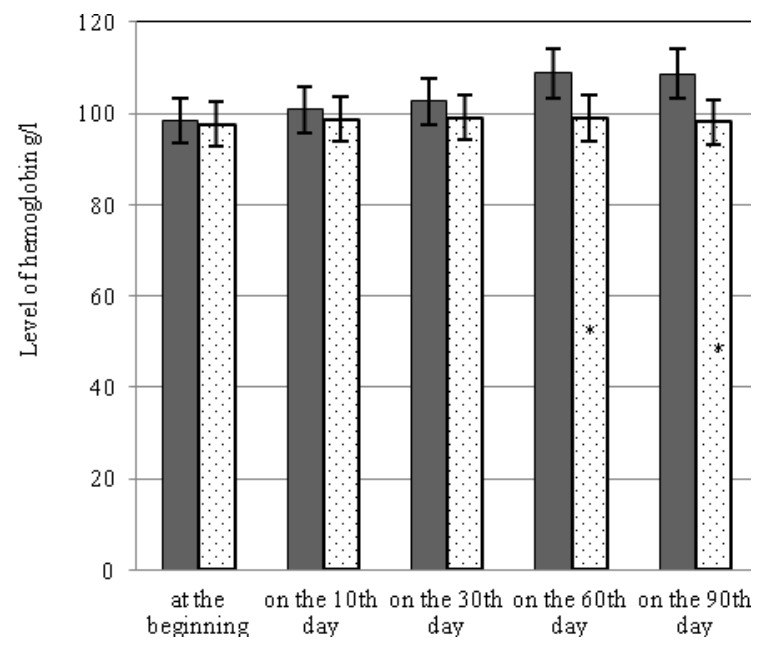

Fig. 4. The impact of Metisevit on the level of hemoglobin in the blood of piglets under nitrate loading: see Fig. 1

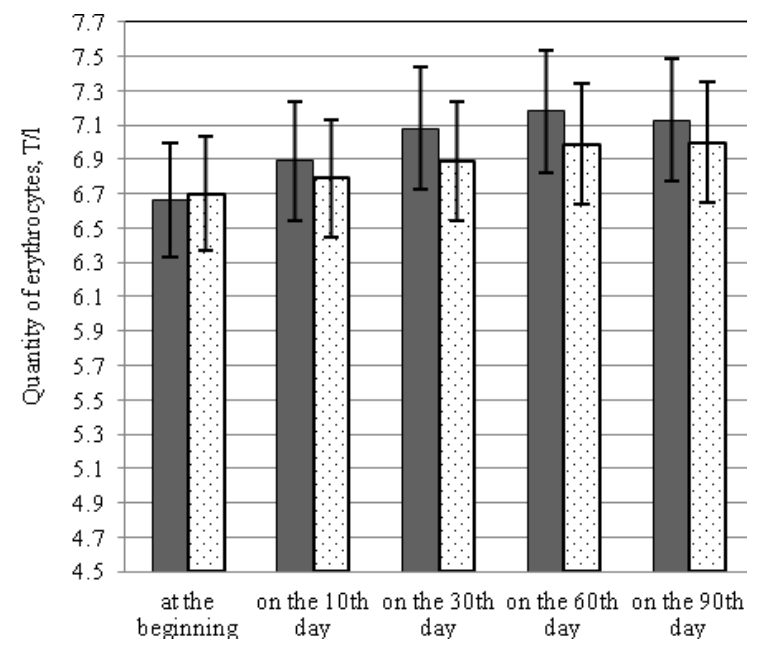

Fig. 5. The impact of Metisevit on the number of erythrocytes in the blood of piglets under nitrate loading: see Fig. 1

Feeding piglets under nitrate loading with fodder which contains Metisevit caused a decrease in the number of leukocytes in the blood of the tested animals: on the 10th day the level of leukocytes had decreased by $3.7 \%$. On the 30th day the number of leukocytes in the blood of the tested piglets was $10.7 \pm 0.30 \mathrm{G} / \mathrm{l}$.

The liver function of piglets under chronic nitrate-nitrite toxicosis was studied through measuring aminotransferase activity, in the blood serum, in particular by measuring the activity of aspartate- and alanine aminotransferase.

We observed that in piglets subject to chronic nitrate-nitrite toxicosis, aminotransferase activity increased in the blood serum of piglets from the control group. By the 10th day of the experiment, aspartate aminotransferase activity had increased by $5.3 \%$, and by the 
30th day - by $8.9 \%$ compared to initial values (Fig. 7). On the 60th day of the experiment, ASAT activity in the blood serum of animals from the control group, which were given sodium nitrate, was $0.426 \pm$ $0.012 \mathrm{mmol} / \mathrm{l} \cdot \mathrm{h}$, which is $18.3 \%$ higher than initial values. ASAT activity continued to increase: on the 90th day of experiment it equaled $0.429 \pm 0.053 \mathrm{mmol} / \mathrm{l} \cdot \mathrm{h}$.

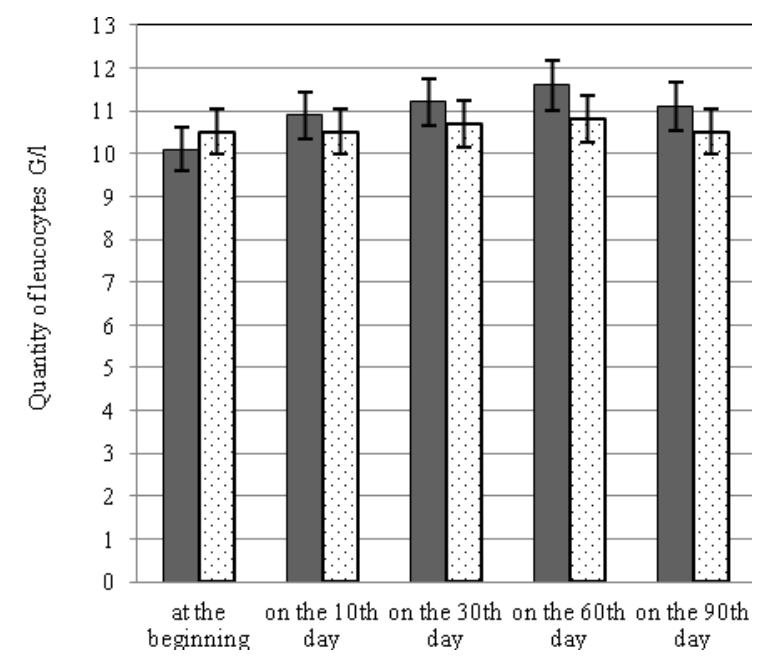

Fig. 6. The impact of Metisevit on the number of leukocytes in the blood of piglets under nitrate loading: see Fig. 1

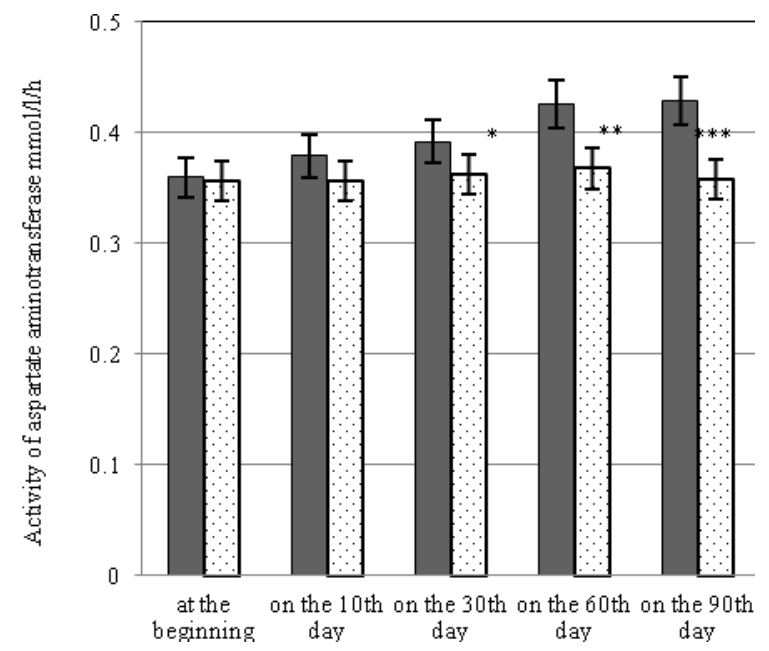

Fig. 7. The impact of Metisevit on aspartate aminotrasferase activity in the blood serum of piglets under nitrate loading: see Fig. 1

Analysis of ASAT activity in the blood serum of piglets fed with Metisevit shows that on the 30th day of the experiment, activity of the enzyme was lower by $7.7 \%$ and on the 60th day of experiment lower by $13.6 \%$ compared to the animals of the control group.

Figure 8 shows the changes in activity of alanine aminotrasferace in blood serum of piglets under the nitrate load and Metisevit. The ALT activity of piglets which at the time were not under nitrate loading fluctuated within the range of $0.215-0.222 \mathrm{mmol} / \mathrm{l} \cdot \mathrm{h}$. After provision of fodder with sodium nitrate by doses of $0.3 \mathrm{~g}$ of nitrate ion $/ \mathrm{kg}$ of body weight, ALT activity in the blood serum of piglets from control group on the 10th day of experiment increased by $29.9 \%$, and on 30th day increased by $45.5 \%$, on 60 th day - by $51.8 \%$, on the 90th day - by $53.2 \%$ in relation to initial values.

Analysis of data on ALT indicators of animals from the experimental and control groups found a significant decrease in activity of the ALT enzyme among the animals from the control group throughout the experiment. On the 10th day, the activity of ALT in the blood serum of animals from the experimental group fluctuated within the range of $0.223 \pm 0.011 \mathrm{mmol} / \mathrm{l} \cdot \mathrm{h}$, whereas among the animals of the control group it was $0.286 \pm 0.013 \mathrm{mmol} / \mathrm{l} \cdot \mathrm{h}$. On the 30th day of the experiment, we observed a decrease by $27.8 \%$ in the activity of the enzyme in the blood serum of animals from the experimental group in relation to initial values. On the 60th day of the experiment, the activity of ALT in the blood serum of piglets from the experimental group showed a slight increase compared to the previous period of research, though it was $28.7 \%$ lower than the values of piglets from the control group. On the 90th day of experiment, the activity of ALT in the blood of piglets from the experimental group reached physiological values.

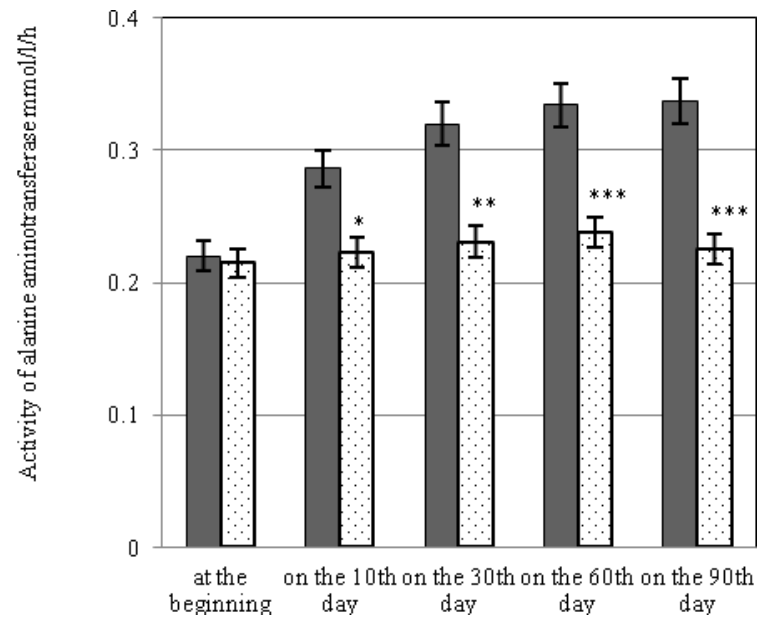

Fig. 8. The impact of alanine aminotransferase activity in the blood serum of piglets under nitrate loading: see Fig. 1

Therefore, increase in activity of aminotransferase - alanine- and aspartateaminotransferase in the blood serum of piglets from the experimental group is possibly conditioned by the fact that nitrites cause damage to cell membranes, and as a result these enzymes along with hepatocytes penetrate the blood. And the more significant the structural damage to biological membranes, the higher the activity of aminotransferas activity. Nevertheless, using the preparation Metisevit (which includes methionine, fenaron and methyphenum) on piglets from the experimental group under nitrate loading caused a heaptoprotective effect, which is manifested by a decrease in aminotransferase activity in the blood.

\section{Discussion}

Production and usage of mineral fertilizers is continuing to increase globally. It is generally accepted that their usage improves agricultural productivity 3-4 times. In such conditions, the key factor of forming crop production is nitrogen, and its main source is nitrates. A number of scholars consider that nitrates are toxic to plants, while their further transformation in the organism of humans or animals can have negative effects (Gutyj et al., 2016). It is scientifically proven that an energy deficient diet, a rapid change of fodder, and incorrect preparation of fodder cause development of substances which are products of incomplete breakdown of nitrates, namely nitrites, which are highly toxic.

Nitrate intoxication of animals causes death of productive young of agricultural animals (Nordkvist et al., 1984; Issi et al., 2008; Gutyj et al., 2016), especially pigs, after weaning, and causes significant economic damage. Therefore, in-depth study of pathogenesis of nitrate-nitrite toxicosis of pigs and methods of its treatment are of great value.

Recent research has shown that nitrate-nitrite toxicosis of agricultural animals is followed by disorders of many systems of the organism, and therefore studying blood is a matter of high priority for any negative effect of foreign agents causes disorder in the morphological content of blood (Gutyj et al., 2016; Khariv et al., 2016; Martyshuk et al., 2016; Gutyj et al., 2017). 
Through our experiments, we demonstrated that nitrates and nitrites have a negative impact on the functional condition of the organism and biochemical indicators of piglets' blood. Over a period of feeding piglets with fodder with sodium nitrate at a dose of $0.3 \mathrm{~g}$ of nitrate ion $/ \mathrm{kg}$, the concentration of nitrates and nitrites in the blood serum increased, and was the highest on the 60th day of the experiment. The high level of nitrates and nitrites in the blood serum of piglets is related to the prolonged provision of nitrates in the fodder. According to data from the literature, this is directly proportional to the intake of nitrates into the organism, i.e. the greater the dose of sodium nitrate fed to animals, the higher the content of nitrates and nitrites in the blood serum (Douglas, 1970; Saito et al., 1996; Gutyj et al., 2016).

The nonuniform increase in the level of nitrates and nitrites in the blood serum of piglets during the experiment could be explained by the gradual adaptation of the organism to excessive amount of nitrates in the fodder and activation of compensatory mechanisms of neutralizing nitrates in the organism of these animals.

The increase in the level of nitrates in the blood of piglets from the experimental group led to formation of methemoglobin, the content of which increased throughout the experiment. It is known that its level in the blood of animals is one of the main diagnostic criteria of nitrate-nitrite toxicosis (Horner, 1982; Robert et al., 1999). The normal content of methemoglobin in the blood of agricultural animals is $2-5 \%$ of total content of hemoglobin, because methemoglobin is always formed during the methabolic processes (Saito et al., 1996; Gutyj et al., 2016).

In the case of experimental chronic nitrate-nitrite toxicosis in pigs, in our experiments we observed that the level of methemoglobin in the blood of piglets from the control group on the 30th day of the experiment was $7.8 \%$, on the 60 th day $-15.1 \%$ and on the 90th day $13.3 \%$. Such a level of methemoglobin in the blood of piglets indicates the development of intoxication. Prolonged feeding of piglets with sodium nitrate at a dose of $0.3 \mathrm{~g}$ nitrate ion $/ \mathrm{kg}$ of body mass causes development of subclinical chronic nitrate-nitrite toxicosis, which is characterized by a high level of nitrates, nitrites and methemoglobin (Douglas, 1970; Gutyj et al., 2016).

Therefore, the results of our experiments concur with the conclusions of other authors on the leading role of methemoglobin in the pathogenesis of nirate-nitrite toxicosis in farm animals (Douglas, 1970; Horner, 1982; Saito et al., 1996). The extent of methemoglobin manifestations depends upon the dose of nitrates, species and age of the animal. In young animals the functioning of methemoglobin reductase is insufficient and so when its activity is low the level of methemoglobin in the blood is higher than among mature animals.

The increase in the level of methemoglobin in the blood of piglets under the nitrate intoxication is manifested also in the level of hemoglobin. On the basis of experimental studies, we have found that there is a gradual rise in the level of hemoglobin, which was highest on the 60th day of the experiment. The increase in this indicator resulted from resistive and adaptive reactions of the organism of piglets exposed to prolonged intake of nitrates and the formation of methemoglobin.

According to the literature, a high level of methemoglobin in the blood causes development of so-called tissue hypoxia (Gutyj et al., 2016; Khariv et al., 2016; Martyshuk et al., 2016), which in its turn provokes morphological and biochemical changes in the blood of piglets and causes significant metabolic changes.

Our experiments proved that if piglets' fodder contains nitrates at a dose of $0.3 \mathrm{~g}$ of nitrate ion $/ \mathrm{kg}$ of body weight, this primarily damages the morphological compound of the blood - one of the most reactive tissues of the organism. Its cells are highly organized and constantly operating complexes. Also they form the morphological basis of homeostasis. Morphological analysis of the quantitative and qualitative compound of blood provides objective data on the functional condition of the hematopoietic system of piglets (Robert et al., 1999; Hariv and Gutyj, 2016).

The aim of our research was to study the changes of certain indicators of the peripheral blood of piglets under chronic nitrate toxicosis. We found that by the 30th, 60th and 90th days of the expe- riment, nitrates had caused an increase in the level of erythrocytes, by $6.3 \%, 8.3 \%$ and $7.1 \%$ respectively. Such changes in the morphological compound of the blood occurred as a result of the irritating impact of nitrates on the mononuclear system with further release of erythrocytes from the blood pool into the blood channel (Gutyj et al., 2016).

We consider that the increase in the level of hemoglobin in the blood of piglets resulted from an increase in the total number of erythrocytes. Thus, in this case an increase in the total volume of blood occurred, which in its turn caused an increase in the level of hemoglobin. Leukocytes in animals' organisms perform protective, transport and trophic functions (Khariv et al., 2016). During feeding of piglets with fodder which contains sodium nitrate at a subtoxic dose, the amount of leukocytes in the blood increased throughout the experiment. Leukocytosis is certainly conditioned by development of inflammatory processes in the gastrointestinal tract impacted by the toxic effect of nitrates and nitrites, which leads to an increase in the number of erythrocytes in the blood of piglets. Similar changes in the increase in the number of leukocytes of animals of different species under chronic nitrate-nitrite toxicosis have been noted in studies by other authors.

Due to the fact that nitrites have a negative effect on the liver, the functioning condition of the liver should be studied in relation to aspartate- and alanine- aminotransferase activity. According to data from the literature, high activity of aminotransferases in the blood serum of agricultural animals, in most cases, is connected with liver failure (Hariv and Gutyj, 2016). Our research found that development of chronic nitrate-nitrite toxicosis of piglets is followed by increase in activity of aspartate- and alanine- aminotransferase in the blood serum. On the 60th and 90th days of the experiment, we observed the maximum activity of aminotransferases in the blood serum of piglets from the experimental group. Also, it should be mentioned that the increase in alanine aminotransferase was greater than that of aspartate aminotransferase. This is related to the fact that ALAT under even insignificant damage to hepatocyte membranes easily becomes released in the blood, whereas AST is contained in the mitochondria of hepatocytes, therefore the release of this enzyme into the blood is more complicated, for apart from the outer membrane of the cell, it should also penetrate through the mitochondria membrane; which can occur in the case of activity of nitrates at high doses (Gutyj et al., 2016).

Thus, chronic nitrate-nitrite toxicosis damages the biological membranes of cells, which results in release of intercellular aminotrasferases from hepatocytes and the cardiac muscle into the blood. The deeper the structural damage to biological membranes of cells, the higher the level of aminotransferase in the blood (Hariv and Gutyj, 2016).

The results of our studies on change in activity of alanine- and aspartateaminotrasferase in the blood serum of piglets under nitratenitrite toxicosis concur with results of studies by other authors on cattle and birds (Douglas, 1970; Medeiros et al., 2003; Gutyj et al., 2016).

The results we provide indicate the usefulness of Metisevit in preventing chronic nitrate-nitrite toxicosis in pigs. The preparation is capable of decreasing concentration of nitrates and nitrites in the blood of piglets, and this, in its turn, leads to decrease in the level of methemoglobin in the blood, where it had decreased to $5.8 \%$ on the 60th day of the experiment. When using Metisevit on piglets under chronic nitrate-nitrite toxicosis, we observed normalization in the number of erythrocytes and hemoglobin in the blood on the 10th day of the experiment. This, perhaps, is a result of recovery of hematopoietic function thanks to the preparation.

The decrease in the number of leukocytes in the blood of piglets from the experimental group is explained by the fact that Metisevit decreases the formation of toxic substances, which contribute to development of inflammatory processes in the intestines and therefore normalizes the number of leukocytes in the blood of animals. For this reason, Metisevit includes zeolite. The adsorbing activity of zeolite causes a decrease in the concentration of agents which can be substrates for development of inflammatory processes in the intestines.

Many researchers mention that the activity of enzymes in blood serum often changes earlier than other biochemical tests, therefore research on the activity of aminotransferases in the blood of piglets is 
highly significant for studying the therapeutic efficiency of preparations in conditions of nitrate-nitrite toxicosis (Khariv et al., 2016; Gutyj et al., 2017). Usage of Metisevit in the conditions of nitrate loading decreased the activity of ASAT and ALT in the blood of piglets from the experimental group, and on the 30th and 90th days of the experiment it fluctuated within the norm of physiological indicators. Changes in activity of aminotransferases in the blood of piglets are explained by the preparation's hepatoprotective action.

\section{Conclusions}

Feeding piglets with fodder containing sodium nitrate at a dose of $0.3 \mathrm{~g}$ nitrate ion $/ \mathrm{kg}$ of body weight increased the concentration of nitrates and nitrites, the level of methemoglobin and hemoglobin, the number of erythrocytes and leukocytes in the blood and activity of aminotransferases in the blood serum. Using methyphenum on piglets under nitrate loading contributed to normalization of morphological and biochemical indicators of the blood of the tested piglets. For preventing chronic nitrate-nitrite toxicosis in pigs, we recommend using Metisevit at a dose of $1 \mathrm{mg} / \mathrm{kg}$ of body weight.

\section{References}

Aslani, M. R., \& Vojdani, M. (2007). Nitrate intoxication due to ingestion of pig weed red-root (Amaranthus retroflexus) in cattle. Iranian Journal of Veterinary Research, 8, 377-380.

Gutyj, B. V., Hufriy, D. F., Hunchak, V. M., Khariv, I. I., Levkivska, N. D., \& Huberuk, V. O. (2016). The influence of metisevit and metifen on the intensity of lipid per oxidation in the blood of bulls on nitrate load. Scientific Messenger LNUVMBT named after S. Z. Gzhytskyj, 18, 3(70), 67-70.

Gutyj, B. V., Murs'ka, S. D., Gufrij, D. F., Hariv, I. I., Levkivs’ka, N. D., Nazaruk, N. V., Gajdjuk, M. B., Pryjma, O. B., Bilyk, O. J., \& Guta, Z. A. (2016). Vplyv kadmiievoho navantazhennia na systemu antyoksydantnoho zakhystu orhanizmu buhaitsiv [Influence of cadmium loading on the state of the antioxidant system in the organism of bulls]. Visnyk of Dnipropetrovsk University. Biology, Ecology, 24(1), 96-102.

Gutyj, B., Khariv, I., Binkevych, V., Binkevych, O., Levkivska, N., Levkivskyj, D., \& Vavrysevich, Y. (2017). Research on acute and chronic toxity of the experimental drug Amprolinsyl. Regulatory Mechanisms in Biosystems, 8(1), 41-45.

Gutyj, B., Martyshchuk, T., Bushueva, I., Semeniv, B., Parchenko, V., Kaplaushenko, A., Magrelo, N., Hirkovyy, A., Musiy, L., \& Murska, S. (2017). Morphological and biochemical indicators of blood of rats poisoned by carbon tetrachloride and subject to action of liposomal preparation. Regulatory Mechanisms in Biosystems, 8(2), 304-309.

Hariv, M. I., \& Gutyj, B. V. (2016). Vplyv liposomalnoho preparatu Butaintervit na proteinsyntezuvalnu funktsiiu pechinky shchuriv za otruiennia tetrakhlor-metanom [Influence of the liposomal preparation Butaintervite on protein synthesis function in the livers of rats under the influence of carbon tetrachloride poisoning]. Visnyk of Dnipropetrovsk University. Biology, Medicine, 7(2), 123-126 (in Ukrainian).

Harvey, M., Cave, G., \& Chanwai, G. (2010). Fatal methaemoglobinaemia induced by self-poisoning with sodium nitrite. Emergency Medicine Australasia, 22(5), 463-465.
Hegesh, E., \& Shiloah, J. (1982). Blood nitrates and infantile methemoglobinemia. Clinica Chimica Acta, 125(2), 107-115.

Horner, R. F. (1982). Suspected ammonium nitrate fertilizer poisoning in cattle. Veterinary Record, 110, 472-474.

Issi, M., Gul, Y., Atessahin, A., \& Karahan, I. (2008). Acute nitrate poisoning in two cattle. Toxicology and Environmental Chemistry, 90, 135-140.

Katabami, K., Hayakawa, M., \& Gando, S. (2016). Severe Methemoglobinemia due to sodium nitrite poisoning. Case Reports in Emergency Medicine, 3.

Khariv, M., Gutyj, B., Butsyak, V., \& Khariv, I. (2016). Hematolohichni pokaznyky orhanizmu shchuriv za umov oksydatsiinoho stresu ta za dii liposomal'noho preparatu [Hematological indices of rat organisms under conditions of oxidative stress and liposomal preparation action]. Biological Bulletin of Bogdan Chmelnitskiy Melitopol State Pedagogical University, 6(1), 276289 (in Ukrainian).

Lee, D. H. K. (1970). Nitrates, nitrites, and methemoglobinemia. Environmental Research, 3(5-6), 484-511.

Martyshuk, T. V., Gutyj, B. V., \& Vishchur, O. I. (2016). Riven produktiv perekysnoho okysnennia lipidiv u krovi shchuriv za umov oksydatsiinoho stresu ta za dii liposomalnoho preparatu "Butaselmevit” [Level of lipid peroxidation products in the blood of rats under the influence of oxidative stress and under the action of liposomal preparation of "Butaselmevit"]. Biological Bulletin of Bogdan Chmelnitskiy Melitopol State Pedagogical University, 6(2), 22-27 (in Ukrainian).

Medeiros, R. M. T., Riet-Correa, F., Tabosa, I. M., Silva, Z. A., Barbosa, R. C., Marques, A. V. M. S., \& Nogueira, F. R. B. (2003). Intoxicação por nitratos e nitritos em bovinos por ingestão de Echinochloa polystachya (capimmandante) e Pennisetum purpureum (capim-elefante) no sertão da Paraíba Nitrate and nitrite poisoning in cattle caused by the ingestion of Echinochloa polystachya and Pennisetum purpureum in the semiarid region of the state of Paraíba. Pesquisa Veterinária Brasileira, 23(1), 17-20.

Nordkvist, M., Rehbinder, C., Mukherjee, S. C., \& Eme, K. (1984). Pathology of acute and subchronic nitrate poisoning in reindeer (Rangifer tarandus $\mathrm{L}$ ). Rangifer, 4(1), 9-15.

Robert, O. W., William, J. L., \& Alan, D. W. (1999). Methemoglobinemia: Etiology, pharmacology, and clinical management. Annals of Emergency Medicine, 34, 646-656.

Saito, T., Takeichi, S., Yukawa, N., \& Osawa, M. (1996). Fatal methemoglobinemia caused by liniment solutions containing sodium nitrite. Journal of Forensic Sciences, 41(1), 169-171.

Todoriuk, V. B., Hunchak, V. M., Hufrii, D. F., Hutyi, B. V., Khariv, I. I., Khomyk, R. I., Vasiv, R. O., Slobodiuk, N. M., Vyniarska, A. V., Zhuravlov, O. I., Husar, P. T., Nazaruk, N. V., Nazaruk, N. I., \& Soltys, M. P. (2017). Doslidzhennia hostroi ta khronichnoi toksychnosti eksperymentalnoho preparatu "Ferosel T" [Research on the acute and chronic toxicity of the experimental medicine "Ferosel T"]. Scientific Messenger LNUVMBT named after S. Z. Gzhytskyj, 73, 104-111 (in Ukrainian).

Todoriuk, V. B., Hutyi, B. V., Khomyk, R. I., \& Vasiv, R. O. (2016). Vplyv ferrovetu 7,5\% i feroselu $\mathrm{T}$ na kontsentratsiiu mineralnykh rechovyn $\mathrm{v}$ syrovattsi krovi porosiat, khvorykh na ferumdefitsytnu anemiiu [Influence of Ferrovet 7.55 and Ferosel $\mathrm{T}$ on concentrations of mineral substances in the blood serum of piglets with ferrum defecit anemia]. Scientific Messenger LNUVMBT named after S. Z. Gzhytskyj, 18, 3(71), 139-143 (in Ukrainian).

Vlizlo, V. V. (2012). Laboratorni metody doslidzhen u biolohiyi, tvarynnytstvi ta veterynarniy medytsyni [Laboratory methods of investigation in biology, stock-breeding and veterinary medicine]. Spolom, Lviv (in Ukrainian). 